\title{
Vanitas vanitatum et omnia vanitas. Językowy obraz marności w tekstach slamerów (na materiale antologii tekstów poznańskiej sceny slamerskiej w 2016 roku)
}

\author{
Vanitas vanitatum et omnia vanitas. \\ The linguistic image of vanity in Polish poetry slam \\ (based on an anthology of the Poznan poetry slam from 2016)
}

\author{
Dagmara Świerkowska \\ Wydział Filologii Polskiej i Klasycznej, Uniwersytet im. Adama Mickiewicza w Poznaniu, \\ ul.Wieniawskiego 1, 61-712 Poznań, Polska; \\ d.swierkowska@gmail.com
}

\begin{abstract}
Abstrakt
Niniejszy artykuł prezentuje pojęcie marności w językowym obrazie świata slamerów skupionych wokół poznańskiej sceny slamerskiej. Bazę materiałową stanowią 34 teksty, wydane w antologii slamerskiej pt. Poetycki freestyle. Poznańska scena slamerska w 2016 roku.

Przeanalizowane teksty zostały uszeregowane w kilka pól tematycznych związanych z obrazem relacji międzyludzkich, religii, miasta i codzienności w tekstach slamerów. We wnioskach klarują się elementy językowego obrazu marności w twórczości slam poetry. Ponadto artykuł podejmuje kwestie związane z określeniem miejsca slamu wśród innych dziedzin sztuki oraz sytuuje go wobec zwrotu performatywnego w kulturze.
\end{abstract}

Słowa kluczowe: slam; językowy obraz świata; vanitas; performatyka.

\begin{abstract}
This article describes the theme of vanity as presented by slam poets from Poznań, based on 34 texts published in an anthology of spoken word poetry Poetic freestyle. Poznań slam scene in 2016.

The analysed texts were arranged into several thematic fields related to the image of interpersonal relations, religion, the city and everyday life as presented in spoken word poetry. The conclusions include elements of a linguistic image of vanity in the works of slam poets. What is more, the article is an attempt at identifying the position of spoken word poetry among other fields of art and juxtaposes it with the performative turn in culture.
\end{abstract}

Keywords: poetry slam; linguistic image of the world; vanity; performative turn; culture.

Tradycyjną historię slamu poetyckiego rozpoczyna pierwsze wydarzenie zorganizowane przez Marca Kellego Smitha w 1984 roku w jednym z chicagowskich klubów. Od tego czasu trwają spory o to, czy twórczość slamerska można uznać za sztuką poetycką lub czy w ogóle jest ona sztuką. Polska historia slamu jest nieco krótsza, gdyż pierwszy slam poetycki odbył się w warszawskiej Starej 
ProchOFFni 15 marca 2003 roku. Niektórzy badacze zauważają jednak, że samo zjawisko tworzenia teksów, które można wygłosić na żywo przed publicznością, ma historyczne korzenie. Doszukują się ich w twórczości wagantów, trubadurów, truwerów oraz barokowych scen ludowych (Gorzkowicz 2013: 203).

Jak zauważają autorzy historii slamu w Polsce w książce pt. Najlepszy poeta nigdy nie wygrywa (Kołodziej 2013), slam poetycki nie doczekał się jednej, przyjętej przez wszystkich definicji, co więcej, nie ma również jednakowych zasad rozgrywania turniejów slamerskich. Organizatorzy slamów poetyckich wyraźnie odróżniają je od wieczorków literackich czy turniejów jednego wiersza, zakładając, że mają one dużo bardziej nieformalną atmosferę.

Turnieje slamerskie znoszą granice między twórcą, a odbiorcami, a nieformalny charakter jest dodatkowo wzmagany przez klubową atmosferę spotkań. Teksty wygłaszane ze sceny są oceniane przez publiczność, która czuje się zaangażowana w wydarzenie ${ }^{1}$. To od jej demokratycznego głosu zależy, kto przejdzie do następnej rundy. Odzew słuchaczy jest niemal natychmiastowy, tzn. wypowiedź slamera może od razu spotkać się z dezaprobatą odbiorców. W najlepszym wypadku nie otrzyma wówczas punktów za swój występ, a w najgorszym - nie dokończy swojej wypowiedzi, gdyż widownia go, najdelikatniej rzecz ujmując, zmusi do zejścia ze sceny.

W stwierdzeniu ,zawładnąć publicznością” kryje się w zasadzie najprostsza definicja tego, co powinien zrobić każdy twórca slam poetry, a przynajmniej ten, który chce pretendować do miana najlepszego. Oznacza to, że slamerski przepis na sukces, wiąże się w dużej mierze $\mathrm{z}$ realizacją postulatów teorii aktów mowy J.L. Austina². Slamerzy poprzez zwroty do publiczności czy wszelkiego rodzaju gry językowe budują pewien obraz siebie i sytuacji lirycznej. Wprowadzają czynności illokucyjne: prośby, rozkazy czy ostrzeżenia, które mają wywołać w widzach określone emocje. Bywa, że sami apelują do widowni, by zagłosowali właśnie na nich. Osiągają swój cel dzięki słowom. Często skłaniają widzów nie tylko do oddania głosów, ale także innych spontanicznych reakcji, będących odpowiedzią na prezentowany przez nich materiał. To odbiorcy nadają tekstowi status dzieła poprzez jawne głosowanie ${ }^{3}$. Wielu slamerów wykorzystuje także

1 Warto dodać, że na widowni pojawia się wielu studentów kierunków humanistycznych, którzy zapewne zwracają uwagę również na kwestie dotyczące formy, języka i stylu.

${ }^{2}$ Choć w pierwotnym ujęciu teoria dotyczy stricte działań o charakterze językowym, została z czasem zapośredniczona przez badaczy kultury i sztuki. Erika Fischer-Lichte używa pojęcia performatywności w kontekście form z pogranicza teatru, słowa i rzeźby, czyli performensów, a także nadania im statusu dzieła sztuki (2008: 34). Pojęcie performatywności rozszerza Maria Gołaszewska, analizując różne wymiary teorii w książce Estetyka $w$ świecie. W kontekście slamu można mówić o performatywnym ujęciu, jako o odziaływaniu słowa i gry aktorskiej slamera, w celu oddziaływania na odbiorcę, a także manipulowania jego emocjami. Warto podkreślić, że występy slamerów są czasami w jakimś stopniu improwizowane, co pokazuje, że sytuacja sceniczna nigdy nie jest do końca pewna i może ulec zmianie w zależności od reakcji i zaangażowania publiki.

${ }^{3}$ Potrafią określić, jakie teksty mogą zdobyć uznanie i tworzą w zależności od potrzeby alternatywną wersję tekstu pierwotnego, by wzmocnić jego funkcję dyrektywną. 
znajomość mowy ciała, wiedząc jak odegrać konsternację, zawstydzenie, dumę czy postawę otwartości wobec publiki. Agata Kołodziej zauważa, że wybory zebranej widowni, które nadają tekstowi status dzieła, są w dużej mierze zinstytucjonalizowane, a relacja między odbiorcą i artystą nie jest wcale równorzędna. Jak wyjaśnia badaczka:

Jednostką ustanawiającą pozostaje w dalszym ciągu autor, który swój zamysł prezentuje. Autor, którego nazwisko w dalszym ciągu firmuje projekt, do którego nas zaprasza w ramach danej instytucji - teatru, literatury, muzyki, nawet jeżeli wydarzenie odbywa się poza przestrzenią do takiej instytucji przynależną. To on przygotowuje projekt [...]. Rola odbiorców zawęża się jedynie do sfery reakcji na to, co artysta przygotował, do współuczestniczenia we wcześniej wykreowanej przestrzeni (Kołodziej 2013: 250).

Jednakże granice między światem autora, a publicznością może zmniejszyć możliwość czynnego współuczestnictwa wyrażona w formie reakcji, publiczność na bieżąco może negować autora, wchodzić na scenę i dopowiadać swoją historię, dokonując tym samym zmiany ról i rozbicia pierwotnego zamysłu twórcy. Uczestnik spotkania nie jest zatem tylko widzem admiratorem, ale wchodzi w rolę współkreatora wieczoru, działając pod wpływem swoich własnych emocji, odczuć i doznań estetycznych ${ }^{4}$. Dystans zmniejsza także tematyka najchętniej podejmowana przez autorów slam poetry, dotyka ona najczęściej codzienności, do której może się ustosunkować każdy odbiorca.

Choć gatunek spoken word nie jest bardzo popularny, a tego typu teksty oralne traktuje się odrobinę drugorzędnie, to odwołują się one do szeroko pojętej tradycji europejskiej, a mianowicie do motywu marności występującego w Księdze Koheleta. Biblijny mędrzec i filozof w swoim dydaktycznym dziele opisuje żywot ludzki przepełniony porażkami i przeciwnościami losu, w którym chwile trudnych doświadczeń wyraźnie przeważają nad momentami błogości, spokoju i zadowolenia. Także codzienność w świecie slamerów nie stwarza powodów do radości, przeciwnie, w wielu wypadkach pozwala mówić o marności. Danuta Kunstler-Langner wyjaśnia, że problematyka marności, przejawia się również w poezji barokowej, a kultura europejska wykorzystywała motyw marności na przestrzeni dziejów z dużą intensywnością i wieloznaczeniowością (1996: 5).

Sama definicja wyrazu marność jest dość szeroka. W Słowniku języka polskiego pod redakcją Witolda Doroszewskiego znajdują się trzy wyjaśnia tego pojęcia, tzn. 'czczość, znikomość, bezcelowość', 'to, co jest bez wartości, czcze, próżne' lub 'marnota' (1962: 467). Natomiast Stownik współczesnego języka polskiego

${ }^{4}$ Gust publiczności nie zawsze może wydawać się spójny z wartością merytoryczną prezentowanych tekstów. Bywa i tak, że pojawiający się na slamie poeta z kilkoma tomikami poezji na swoim artystycznym koncie nie zyskuje uznania slamowej publiczności i odpada w pierwszej rundzie, przegrywając z młodym debiutantem, który zawładnął publicznością. 
pod redakcją Bogusława Dunaja definiuje ją jako: 'znikomość, bezcelowość, brak wartości czegoś' (2001: 494).

Marność relacji międzyludzkich jest częstym zagadnieniem w tekstach poznańskich slamerów. Temat nietrwałości i bezcelowości pojawiał się w przestrzeni relacji damsko-męskich oraz kontaktów koleżeńskich. W artykule analizuję językowy materiał z antologii tekstów slamerskich pt. Poetycki freestyle. Poznańska scena slamerska w 2016 roku wydanej w 2017 roku pod redakcją A. Budnik, M. Mikulewicza i M. Dworka przez Fundację na Rzecz Kultury Akademickiej (obecnie organizacja nazywa się Fundacja KulturAkcja)5. W tekstach slamerskich marność dotyczy kilku pól tematycznych: doświadczeń codzienności, relacji z kobietami, relacji z mężczyznami, miasta, polityki i wiary.

Slamer o pseudonimie Carlo Lorens w tekście pt. Kalos kai aghatos tworzy spójny obraz bohatera, który we współczesnej rzeczywistości chciałby realizować starożytny postulat kalokagatii, ale otaczający go świat, przeszkadza mu w jego realizacji. Twórca wykorzystuje metaforę drogi, by pokazać bezwartościowość życia. Jego długość i monotonia świadczy o jego marności, a autor to podkreśla, używając określeń: złość i niespetnienie. Jednocześnie wskazuje, że drogę tę przemierzają ludzie, którzy z natury są dobrzy, o czym świadczy wyrażenie piękne istnienia. Stosuje hiperbolę uwiktani w setki ról na określenie faktu ukrywania we współczesnym świecie własnego ja, które jest niewystarczające, zbyt niedoskonałe i wymagające polepszenia, tym samym pokazuje jego marność i bezwartościowość. Jego bohaterowie żyją w szybkim tempie, ale ze względu na brak czasu, nie mają także czasu na uczucia, taki tryb życia jest negowany przez autora. Jego bezcelowość podkreśla użycie określenia akt miłości na opis relacji damsko-męskich. Sprowadzenie wartościowego uczucia jakim jest miłość, do zwykłego aktu jest zabiegiem, który również podkreśla marność codzienności. Autor wykorzystuje także zabieg reifikacji, przyrównując ludzi do przedmiotów, które mogą się zakurzyć. Pisze, że ludzie, którzy nie mają czasu na relacje międzyludzkie, nawarstwiaja kurz. Kurz ma tutaj wartość symboliczną. Kojarzony z brudem, a także przemijaniem, po raz kolejny pokazuje bezcelowość egzystencji.

O marności relacji damsko-męskich z perspektywy kobiety pisze krakowska slamerka Rudka Zydel. W Ćwiczeniach z empatiil bólu dupy wykorzystuje wiele epitetów wskazujących na negatywny stosunek do świata mężczyzn. Pojawiają się określenia: lepka dłoń; stary cap; przepocony ortalion, a także rozbudowane porównania: nie jesteś publicznym kiblem, do którego można wleźć tylko dlatego, $\dot{z}$ e jest wolny; facet to nie brukselka, nie musisz raz spróbować, żeby wiedzieć, że Ci się nie podoba; siedzi rozwalony jakby miat co najmniej cztery jądra. Przesączone językiem potocznym, tworzą obraz współczesnej kobiety, która nie dostrzega w mężczyznach nic wartego uwagi, uważa ich za troglodytów pozbawionych uczuć. Są dla niej istotami bezwartościowymi, które nie determinują w żaden sposób jej decyzji i życiowych celów. Tym samym wpisują się w zagadnienie

${ }^{5}$ Wszystkie cytaty tekstów slamerów są w niniejszym tekście przywoływane za tym wydaniem. 
marności relacji damsko-męskich we współczesnym świecie. W tekstach Rudki Zydel pojawiają się również metafory związane z osobami znanymi, bohaterka tekstu, jadąc autobusem pełnym mężczyzn, zaplata nóżkami najciaśniejszą Jaworowicz świata, co jest odwołaniem dla charakterystycznej postawy siedzącej Elżbiety Jaworowicz, jednej z polskich publicystek. Bohaterka przybiera taką pozę, by zrobić jak najwięcej miejsca zajmującym dużo miejsca, rozwalonym mężczyznom i by nie zwracać na siebie uwagi. Bohaterka przytacza też związek frazeologiczny 'podnieść rękę na kogoś', wykorzystując go w kontekście przedstawienia męskiego ideału w opinii starszego pokolenia, określonego jako ludowa mądrość, tym samym polemizuje z wartością tej ludowej mądrości, która jawi się jej jako przestarzały zbiór niesprawiedliwych zasad, przyzwalający na znikome ślady szacunku względem kobiet. W tekście pojawiają się liczne wyrażenia wulgarne, które podkreślają brud relacji damsko-męskich: walić sobie konia; ściaga ci gacie; goła dupa. Wulgaryzacja języka Rudki Zydel dotyczy mówienia o życiu seksualnym, wyrażenia są nacechowane negatywnie, ukazują stosunek seksualny jako coś zwierzęcego, odzierającego z godności i występnego. Na samym końcu, pojawia się zwrot do odbiorcy mający funkcję ekspresywną wyrażoną w formie gratulacji:

Jeśli to wszystko zmieściło Ci się w głowie, to gratuluję, chociaż raz poczułeś jak to jest być kobietą (2017: 76).

Jest to bardzo ironiczny zwrot do odbiorcy, wyrażony na scenie ma zawstydzić obecnych na widowni mężczyzn. Pokazuje tym samym, że poezja spoken word oddziałuje nie tylko poprzez słowa, ale poprzez sytuację, a także autora, który reprezentując określoną płeć, narodowość czy grupę społeczną. W wypadku tej puenty podkreślony zostaje trud bycia kobietą, beznadziejność kobiecej codzienności.

Daremność relacji koleżeńskich przedstawia w swym tekście Roman Franczyk. Adam przyszedt, zapalit i poszedt do kuchni przywołuje styl biblijny przez kilkakrotne użycie wołacza: $O$ Adamie, $O$ Romanie na początkach kolejnych zdań. $\mathrm{W}$ domu panuje chaos, jest to klasyczne mieszkanie wynajmowane przez kilku obcych sobie ludzi, których łączy tylko fakt przebywania w jednym mieście, ale nie są oni rodziną. Nie mieszkają też w domu rodzinnym, a więc żyją w rzeczywistości, w której trudno się zakorzenić. Autor nawiązuje do Biblii także poprzez odwołanie do Sodomy i Gomory, gdy mówi o tym, co dzieje się w jego domu: brak wzajemnych kontaktów, rozmów, anonimowość, palenie papierosów, drobne sprzeczki, które nie poprawiają jakości codziennego życia. W tekście pojawia się błąd leksykalny sodomia i gomoria. Zastosowanie takich form ma na celu zdemaskowanie potocznej wiedzy otaczających go ludzi, którzy używając biblijnych zwrotów, wykrzywiają ich znaczenie, co pokazuje brak szacunku do Pisma Świętego i jego najczęściej cytowanych fragmentów. W formie wyliczenia przedstawia 
pretensje, które pod jego adresem wnosi sąsiad, a określając owe pretensje, używa slangowego zwrotu 'sadzić się o coś':

[...] cały czas się o coś sadzi. Że auto krzywo stoi,

że u mnie sodomia się pleni i gomoria;

że mlecze z mojego ogródka mnoża się na jego ogródku (2017: 21).

Podobnie jak w innych tekstach, bohater jest postacią marzącą wyłącznie o normalnym życiu, gdyż nie może czerpać satysfakcji z relacji międzyludzkich.

Marność dotyczy także wiary i religii. W tekstach slamerskich pojawiają się najczęściej wypowiedzi $\mathrm{w}$ formie asercji, przejawiające się zwątpieniem i niepewnością. Slamerzy podkreślają wielość religii, a w zasadzie wyznań, które, istniejąc obok siebie, walczą o wiernych. To wprowadza zamęt w głowach ludzi i zmusza ich do zastanawiania się nad wartością wiary w ogóle. Carlo Lorens stosuje zabieg antropomorfizacji, pisząc o tym, że bóg się wymyka. Wybrany przez slamera zapis, wskazuje, że w ludzkim życiu brakuje miejsca na szacunek dla Boga chrześcijańskiego, gdyż dookoła czai się mnóstwo innych wartości, które rywalizują ze sobą o status nadrzędnej boskości. Wszystkie one są jednak czcze i próżne. To wiąże się także $\mathrm{z}$ brakiem wiary w istnienie życia pozagrobowego. Pojawiają się określenia nikt nie może wiedzieć u Carlo Lorensa, a także będę się platat nie mogąc znaleźć tego pieprzonego światta na końcu tunelu $\mathrm{w}$ tekście Marka Jury pt. Wiesz co. Epitet pieprzony przed związkiem frazeologicznym zobaczyć światto $w$ tunelu jest wykorzystany w celu wartościowania negatywnego, tzn. wiara w spotkanie z Istotą Najwyższą po śmierci jest dla autora bardzo niepewna, a użycie wyrazu potocznego związanego z czynnością seksualną, stanowi też podkreślenie marności przemijania. Podmiot liryczny jest przerażony faktem zagubienia, podobnie jak podmiot tekstu Dom Carlo Lorensa, który przyznaje: nie wiem czy w cokolwiek wierzę i to zaczyna przyttaczać mnie. Ta pełna zwątpienia deklaracja, pozwala ulokować artystę w grupie twórców antropocentrycznych, którzy poprzez szereg doświadczeń utracili wiarę w życie pozagrobowe, co oddala od tradycji religijnej (związanej z Ksiegga Eklezjastesa, antykiem, barokiem czy romantyzmem), w której życie wieczne było nagrodą za ziemską marność i niedolę. Slamer stosuje w tym zdaniu przerzutnię, potrzebną do wyzyskania rymu. To zabieg charakterystyczny dla tego twórcy, wywodzącego się ze środowiska hip-hopowego, choć w tym wypadku ma on charakter czysto formalny.

Marność uwidacznia się także w tworzonym obrazie otaczającego świata, tzn. w określeniach miasta, szarego, nieprzyjaznego i prymitywnego. W tekście Moniki Łukomskiej pt. Chaos Poznań pojawia się wiele elementów leksykalnych zaczerpniętych z gwary miejskiej Poznania: plyndze, pyry, kejtry, siatki, wiara, bimba. Tekst ma także wartość onomastyczną, pojawiają się w nim nazwy największych poznańskich centrów handlowych: plaza, malta, browar, sziti center. Są to potoczne skróty nazw własnych, a ich użycie sprawia, że tekst przypomina bardziej tok rozmowy, a opuszczenie wyrażenia centrum handlowe nadaje tempa 
wypowiedzi poetyckiej, wskazuje też, że są to miejsca ogólnie znane i często odwiedzane. W oczach autorki uchodzą one za nieszczególnie wartościowe. W wypadku ostatniego pojawia się błędny zapis angielskiej wymowy wyrazu city w taki sposób, by brzmiało ono jako derywat od wyrazu shit (ang. 'gówno'). W utworze znajdują się liczne gry słowne, opisujące obskurność miasta: Kamienice jada moczem, a tramwaje menelami; Przechadza się po galerii jak więzień po spacernia$k u$. Kilkakrotnie pojawiają się wulgaryzmy: gówno; dupa, a także wyrażenie slangowe: pety czy zapożyczenie z języka angielskiego, także charakterystyczne dla języka młodzieżowego: hajs. Wyrażenia te, mając charakter potoczny, są wyraźnie nacechowane negatywnie. Tworzą brudny obraz miasta z używkami, nocnymi klubami, galeriami handlowymi i pieniędzmi w tle. Każda z wymienionych rzeczy, choć stworzona z myślą o ludziach, ogranicza bądź odbiera im ich człowieczeństwo, nie dodając codziennemu życiu żadnych wartości.

W przywoływanym w tekście pojawia się wiele elementów toponimii miejskiej w postaci nazw dzielnic Poznania, które przy okazji odwołują się do stereotypowego wizerunku tych części miasta. Jeżyckie jeże i wildecki szatan, to częste elementy występujące w lokalnych opowiadaniach, utworach raperskich czy tekstach publicystycznych. Natomiast stwierdzenie 'po Starym Rynku przechadzają się panie z parasolkami' sugerowałoby, że to opis miejskiej sielanki, ale znajomość kontekstu, pozwala zrozumieć, że wpisana jest w nie ironia, gdyż chodzi o prostytutki przechadzające się po Starym Rynku w okolicach jednego z klubów nocnych. Urokliwe panie zostają odczarowane, a ich opis wpisuje się w krajobraz marności Poznania, jako miejsca złego i grzesznego.

Na Jeżycach ${ }^{6}$ za to mieszkają jeże, w dresach,

a na Wildzie szatan.

Po Starym Rynku przechadzają się panie z parasolkami,

cholera nawet w te dni, w które nie pada (2017: 52).

Wymieniane kolejne nazwy ulic i miejskich lokalizacji najczęściej występują w formie podstawowej, ale w niektórych sytuacjach są dookreślone przy wykorzystaniu wartościującego negatywnie epitetu: Kaponiera; pierdolone Żeromskiego; Rataje; Naramowice, co pogłębia u odbiorców odczucie marności miasta.

Inna część Poznania została opisana w tekście Poznań. Wielkie ambicje, Mate Garbary Zuzanny Krzyżanowskiej. Miasto w utworze jest miejscem bezludnym, nieobecnym, wypełnionym tylko przez bezosobowe przestrzenie architektoniczne. Autorka wymienia następujące elementy leksykalne: nocne sklepy, piwnice, pustostany, powierzchnie biurowe, urzędy skarbowe, komisariaty policji, kanaty. Skupia się zatem na miejscach, które kojarzą się z brudem, odczłowieczeniem. Wymienia przestrzenie budzące niechęć, strach czy obrzydzenie, tzn. takie, w których żaden człowiek nie czuje się komfortowo. Miejsca bezwartościowe,

\footnotetext{
${ }^{6}$ Nazwa patronimiczna z przyrostkiem -ic- (por. Zagórski 2008: 139).
} 
świadczące o marności ludzkiej egzystencji w przestrzeniach miasta. Poznań jest miejscem zła, wytwarzającym zatruty alkohol i tabletki gwałtu, określane eufemistycznie tabletkami podawanymi w nocnych klubach. Autorka używa metaforycznego wyrażenia krajobraz nieregularna, rysowana niepewnie linia, by stworzyć wizerunek miasta, które chyli się ku upadkowi, miejsca przemijającego, tym samym wpisuje się w tradycję motywu vanitas.

Ciekawym elementem antologii jest tekst Jakuba Jagiełly pt. Światła, który przy pomocy gradacji, rozbudowuje wers światta rozplywaja się we mgle. Zastosowany przez twórcę zabieg namnażania kolejnych epitetów i porównań, tworzy nocny pejzaż złożony z ulicznych latarni, świateł samochodów i wilgotnego powietrza:

światła rozpływają się we mgle.

Światła bardzo ładnie rozpływają się we mgle.

Światta niesamowicie nierealnie rozplywaja się we mgle.

Lśniące widmem emisyjnym sodu światła poustawianych tu i ówdzie latarni niesamowicie nierealnie rozpływają się cudownym gradientem w niezwykle pięknej, gęstej, nocnej mgle (2017: 26).

Nocna impresja zaczyna się jednak od powtórzenia: Nicość, nicość i cierpienie, które można zinterpretować jako nawiązanie do biblijnej sentencji zaczerpniętej od Koheleta vanitas vanitatum et omnia vanitas (Koh 1,2). Występujące w tekście światło, pomimo swojej tradycyjnej symboliki związanej z Bogiem, oświeceniem, jest tutaj wartościowane negatywnie, gdyż jest to światło nocnej latarni, pod którym może czaić się zło. Ponadto wykrzywia ono sylwetki ludzkie, gdy jest zbyt słabe, wprowadza poczucie niebezpieczeństwa, podkreśla pustkę i ciemność wokół. Jest to typ światła, który nie oświeca żadnej ze spraw, nie daje poczucia bezpieczeństwa. Stworzony przez Jakuba Jagiełłę obraz jest niezwykle plastyczny, nagromadzenie epitetów wyrażających zachwyt, przywodzi na myśl monolog osoby, która, wracając samotnie w nocy przez miasto zła, próbuje się uspokoić, tworząc coraz bardziej rozbudowane zdania i wyliczenia. W takim kontekście tekst nabiera charakteru illokucyjnego, ma on stworzyć sytuację bezpieczeństwa.

Marność miasta pojawia się także w tekście Patryka Nadolnego Tak to jest. Wyraża się w rozbudowanych porównaniach, uwznioślających potoczność poprzez wykorzystanie kontrastowych elementów: wysokiego stylu i leksyki związanej z prymitywną codziennością:

Pod płotami stoją butelki piwa - puści i do cna zapomniani

szklani bogowie nieistniejących światów,

na oszronionej trawie leżą zwoje prezerwatyw

jako pradawne i nierozszyfrowane teksty o miłości (2017: 63). 
Nadolny podobnie jak Carlo Lorens umniejsza wartość miłości, sprowadzając ją tylko do aktu seksualnego. Fakt, że zwoje prezerwatyw leżą na oszronionej trawie, wskazuje na przypadkowość partnera, a także miejsca stosunku. W tekście pojawia się metafora szklani bogowie, pokazująca, że w świecie ziemskiej marności, to alkohol jest bóstwem nadrzędnym i kreatorem rzeczywistości. Autor nie wartościuje tego zjawiska w żaden werbalny sposób, ale emocje towarzyszące jego odczytaniu na scenie, jasno wskazują, że taki stan rzeczy jest nieakceptowany. Podobnie jak u Carlo Lorensa, także u Patryka Nadolnego prezentowana jest wizja świata bez Boga, świata upadku, w którym egzystencja jest pozbawiona sensu.

W tekstach zebranych w poznańskiej antologii nie brakuje także rozczarowań codziennością. Metaforę życia jako sformalizowanego wypełniania ankiety stworzył Artur Bandelak w tekście Usiądź pan. Poprzez zwrot do odbiorcy, tekst przypomina rozmowę prowadzoną $\mathrm{w}$ banku bądź w urzędzie. Zastosowanie wulgaryzmów i powtórzeń sprawia zaś, że tekst staje się bardziej ekspresywny, co kontrastuje $\mathrm{z}$ wizerunkiem ospałego urzędnika, któremu na niczym nie zależy:

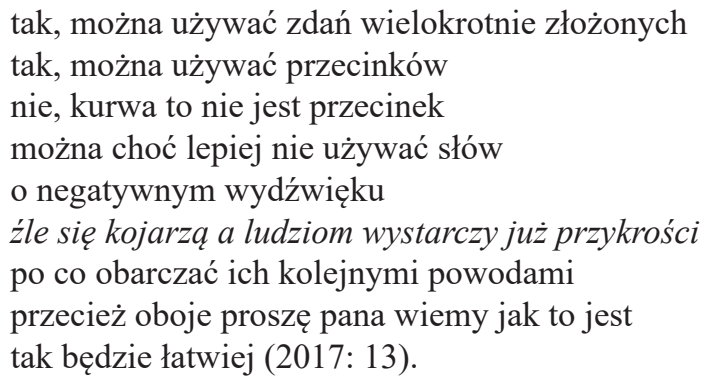

W cytowanym tekście istotne są funkcje dyrektywna i ekspresywna. Zyskuje on na wartości podczas wygłaszania na żywo, co jest charakterystyczne dla wielu tekstów tworzonych przez slamerów.

Ciężarem dla slamera jest także niemożność osiągnięcia popularności w dziedzinie sztuki czy nauki. Grę słów polegającą na wykorzystaniu nazwisk znanych fundatorów światowych nagród oraz naukowców związanych z medycyną i biologią wprowadził do tekstu Wiesz co Marek Jura:

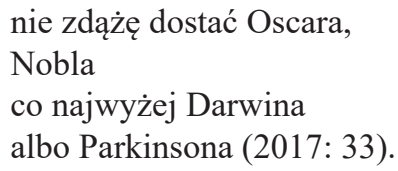

Oprócz Oscara i Nobla, nagród nadających materialną, ale także medialną wartość twórcom filmowym oraz naukowcom, pojawia się tutaj Parkinson, choroba zwyrodnieniowa środkowego układu nerwowego. Jest ona charakterystyczna dla osób w starszym wieku, a jej głównym objawem jest drżenie całego ciała. Kojarzy się z brakiem samodzielności, a jej postępujący rozwój jest zapowiedzią 
kresu życia. Jurga w swoim tekście podkreśla marność egzystencji współczesnego artysty. Pozbawiony szans na rozwój, uznanie i jakiekolwiek korzyści majątkowe może on liczyć tylko na zbliżającą się i postępującą w toku choroby śmierć. Prezentowany tutaj wizerunek artysty jest istotny także z punktu widzenia tradycji europejskiej. Poeci europejscy, mający status „wielkich”, najczęściej byli nobilitowaniu już za życia, a po śmierci niemalże przyrównywani do bóstw. Autor czuje, że te czasy juz minęły, a jego twórczość nie jest horacjańskim exegi monumentum, okazuje się więc marnoscią.

Norymberga $n r 2$ Marka Jury nawiązuje do głośnych procesów norymberskich przeciwko zbrodniarzom III Rzeszy. Jednak w tym tekście na ławie oskarżonych zasiadają mięsożercy. Mocna metafora, polegająca na porównaniu działań nazistów do jedzenia wyrobów mięsnych, swoją budową przypomina litanię. Elementem kontrastującym jest w tej mowie oskarżycielskiej użycie wulgaryzmu pierdel:

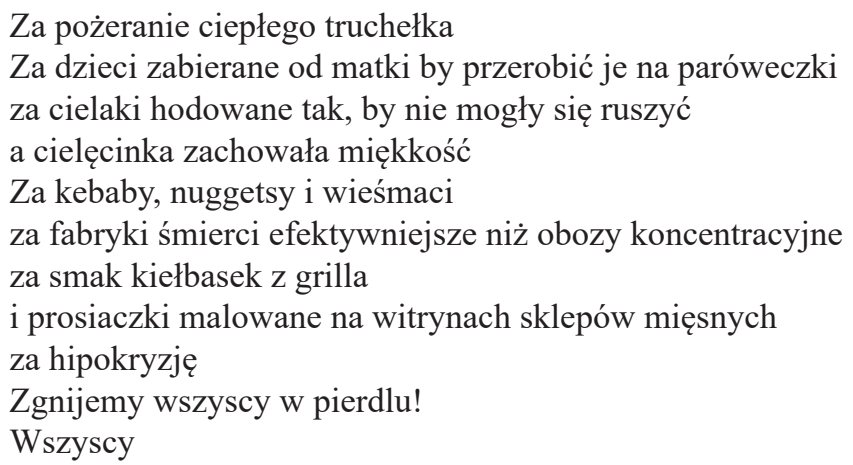

To koniec! (2017: 29).

Tekst kończy się przewrotnie, mową konkludującą karpia, którego udaje slamer, wydając odgłos kłapania ust. Pokazuje tym samym, że jakakolwiek próba podsumowania egzystencji w świecie bez wartości transcendentnych jest pozbawiona sensu. Artysta naśladuje zwierzę, które nie może zabrać głosu, ponieważ sam nie chce lub już nie potrafi być komentatorem marnej rzeczywistości.

Teksty slamerów są napisane językiem pełnym wyrażeń potocznych, wulgaryzmów oraz elementów slangowych. Ze względu na to, że materiał został stworzony głównie przez osoby mieszkające w Poznaniu, pojawia się w nich wiele elementów lokalnych zarówno zakresu słownictwa gwarowego, jak i toponimii. Użycia tych nazw nie są bezcelowe, ponieważ przywołują one konteksty, a także pokazują stosunek zaangażowanych społecznie slamerów do niektórych inicjatyw, dzielnic czy budynków użyteczności publicznej. Slamerzy, opisując miasto, posługują się środkami, które mają pokazać jego nadzwyczajną marność. W ich wypowiedziach nie ma miejsca na wzniosłe uczucia, opis pięknych budynków, miejsc, wydarzeń czy radości uczestniczących w nich dzieci. Utwory opisują sceny nocne, brudne, chwilami brutalne, a budowany przez nich obraz pokazuje 
negatywny stosunek do miasta. Poznań jest opisywany niczym biblijna Sodoma i Gomora, miasto upadku człowieka, w którym doczesność ze swoimi przyjemnościami liczy się bardziej niż życie wieczne.

$\mathrm{W}$ tekstach zebranych $\mathrm{w}$ antologii slamerskiej pojawiło się wiele odwołań do kultury europejskiej: chrześcijaństwa, antycznej filozofii, a także literatury, co świadczy o pewnym potencjale kulturowym i świadomości humanistycznej twórców. Nie brakuje odwołań do kultury popularnej: kina, komiksów czy reklam telewizyjnych. Zestawienia kultury wysokiej i masowej oprócz tego, że stanowią postmodernistyczną grę z konwencją, mówią coś także o współczesnym życiu młodych ludzi. Przepełnione bodźcami nie pozwala na skupienie się na rzeczach wzniosłych i ważnych, ale sprawia czasem, że bóg się wymyka, a życie w pędzie powoduje szybkie wypalenie, brak chęci do działania i utratę wiary w sens istnienia, co także znajduje się w polu semantycznym marności.

Slamerzy wykorzystują w niewielkim stopniu związki frazeologiczne, za to korzystają chętnie z metafor i rozbudowanych porównań, które pozwalają im opisać w bardzo plastyczny sposób rzeczywistość. Wykorzystywanie gier słownych czy błędów językowych często ma dodatkową wartość podczas odbioru tekstu na żywo, przyciąga uwagę widzów, jest też przyczynkiem do wprowadzenia do wystąpienia gestykulacji czy elementów gry aktorskiej. Jak podkreślałam niejednokrotnie, często dźwiękowy odbiór tekstu pozwala na uwypuklenie emocji, które autor chce przekazać. Dopiero odczytanie może w wielu wypadkach pokazać, że slamer neguje pewne zjawisko. Wykorzystanie mowy ciała oraz emisji głosu w wypowiedziach slamerskich uwypukla intencję autora i powinno być nieodłącznym elementem interpretacji.

W slam poetry świat współczesny to rzeczywistość bez wzniosłych uczuć jak miłość, dobro czy piękno. W tekstach slamerek występują mężczyźni, którzy nie mogą zapewnić kobiecie bezpieczeństwa, nie dostrzegają jej wewnętrznego piękna, ale patrzą na nią wyłącznie w kategoriach cielesnych. Kobieta w świecie mężczyzn nie czuje się bezpieczna, nie wie, kiedy i w jakiej sytuacji może spotkać ją jakieś zagrożenie. Jest sama, ale nie samotna. Decyduje się na życie w pojedynkę, by uniknąć odarcia z godności. Życie to opiera się tylko na przypadkowych kontaktach fizycznych. Ciekawym zjawiskiem jest to, że w przeciwieństwie do kobiet, slamerzy rzadziej używają pierwszej osoby, tak jakby chcieli uniknąć poczucia, że opisują własne życie. Kreowane przez nich obrazy nie są przez to aż tak intymne i przybierają formę opisów zepsutego świata. Mówią o brudnych ulicach z walającymi się prezerwatywami i o miłości nie jako uczuciu, ale jako o akcie, który przywodzi na myśl jego fizyczny wymiar. Są w świecie samotni i brakuje im kobiety, która nada cel i sens ich istnieniu, a nie będzie tylko przypadkową towarzyszką jednej nocy.

Te zachwiane relacje damsko-męskie także wpisują się w obraz marności. Uwypuklają się w nich złe doświadczenia związane z pożądaniem, stosunkami seksualnymi i przypadkowością tychże. Stanowią przykład ziemskich rozkoszy, które mogą uchodzić za bezwartościowe i próżne, jeśli nie wynikają z uczuć. 
Teksty slamerów są zaangażowane społecznie i bardzo aktualne. Poruszają często tematy chwilowych afer politycznych czy skandali z życia celebrytów, które po jakimś czasie przestają być zrozumiałe, co może utrudnić ich interpretacje. Ta „chwilowość” utworów mówi także o marnej i czczej kondycji świata opisywanego przez twórców. Małe skandale zaprzątają uwagę ludzi, sprawiają, że skupiają się na bezwartościowych sytuacjach. Wszystkie te elementy wpisują się w kontekst vanitatywny. Pokazują, że ziemskie rozkosze, ale także zaburzone, konfliktowe relacje międzyludzkie są wyznacznikiem nie tylko współczesności, ale ogólnie rzecz ujmując - życia ludzkiego. Problemy o charakterze egzystencjalnym, poszukiwanie Istoty Najwyższej, celu życia czy wzniosłych uczuć są poruszane przez twórców wszelakich gatunków sztuki od początków kultury, a tym samym mają charakter uniwersalny.

Zebrane w Antologii slamerskiej z roku 2016 prace traktują głównie o życiu w mieście pełnym szarości, brudu i obcości. Slamerzy dostrzegają upadek wartości relacji międzyludzkich, mają problemy z akceptacją codzienności, są osobami, które poszukują własnego miejsca i próbują zmierzyć się z kwestiami religijnymi. Elementy związane z rozczarowaniem życiem, zakłamaniem, poczuciem obcości w świecie, bezcelowością, brakiem wiary w ludzi i w miłosierdzie Boga, a także przemijaniem oraz nieładem i chaosem wpisują się w pole terminologiczne motywu marności, stanowiącego jeden z fundamentalnych elementów kultury europejskiej. Włączają się tym samym $\mathrm{w}$ interdyscyplinarny dyskurs humanistyczny związany z ideą vanitas i kontynuują ją, przedstawiając nowy nurt, w którym oprócz opisu zjawisk wartościowanych negatywnie pojawia się też element manifestu, gdyż tekst wygłaszany ze sceny ma inną moc sprawczą i wpływa na odbiorców w zupełnie inny, bardziej dogłębny sposób, skłaniając go do natychmiastowej refleksji.

\section{Bibliografia}

Bartmiński J. (red.), 2004, Językowy obraz świata, Lublin.

Budnik A., Dworek M., Mikulewicz M. (red.), 2017, Poetycki freestyle. Poznańska scena slamerska w 2016 roku, Poznań.

Doroszewski W., 1962, Słownik języka polskiego, t. 4, Warszawa.

Dunaj B., 2001, Słowniki współczesnego języka polskiego, t. 1-2, Kraków.

Fischer-Lichte E., 2008, Estetyka performatywności, tłum. M. Borowski, M. Sugiera, Kraków.

Gorzkowicz J., 2013, Czy slamer jest wspótczesnym wagantem? Praktyki performansu poetyckiego wobec tradycji średniowiecznych, w: Najlepszy poeta nigdy nie wygrywa. Historia slamu w Polsce 2003-2012, red. A. Kołodziej, Kraków, s. 200-217.

Grad J., 2005, Teoretyczno-metodologiczne problemy badań ludycznej aktywności człowieka, w: Kultura, komunikacja, podmiotowość. Szkice epistemologiczno - kulturoznawcze, red. K. Zamiary, Poznań, s. 123-135. 
Jastrzębska J., 2013, (R)ewolucja performatywna zjawisk scenicznych. Od salonu do slamu, w: Najlepszy poeta nigdy nie wygrywa. Historia slamu w Polsce 2003-2012, red. A. Kołodziej, Kraków, s. 177-197.

Kołodziej A. (red.), 2013, Najlepszy poeta nigdy nie wygrywa. Historia slamu w Polsce 2003-2012, Kraków.

Kołodziej A., 2013, Odbiorca na fotelu krytyka. Slam przeciwko instytucjonalizacji sztuki, w: Najlepszy poeta nigdy nie wygrywa. Historia slamu w Polsce 2003-2012, red. A. Kołodziej, Kraków, s. 246-263.

Kunstler-Langner D., 1996, Idea vanitas, jej tradycje i toposy w poezji polskiego baroku, Toruń.

Pease A., 2001, Mowa ciała. Jak odczytywać myśli innych ludzi z ich gestów, thum. P. Żak, Kielce.

Zagórski Z., 2008, Nazwy części miasta (dzielnic, osiedli, wsi, osad miejskich), w: Nazewnictwo geograficzne Poznania. Zbiór studiów, red. Z. Zagórski, Poznań, s. 31-164. 